\title{
Auditory abilities stimulation in preschoolers
}

Universidade Estadual Paulista "Júlio de Mesquita Filho" - UNESP, Programa de Pós-graduação em Fonoaudiologia, Marília, São Paulo, Brasil.

2 Universidade Estadual Paulista "Júlio de Mesquita Filho" - UNESP, Departamento de Fonoaudiologia, Marília, São Paulo, Brasil.

\section{A study carried out in the Speech- Language Pathology and Audiology Course, Universidade Estadual Paulista "Júlio de Mesquita Filho" - UNESP - Marilia, São Paulo, Brazil.}

\section{Conflict of interests: Nonexistent}

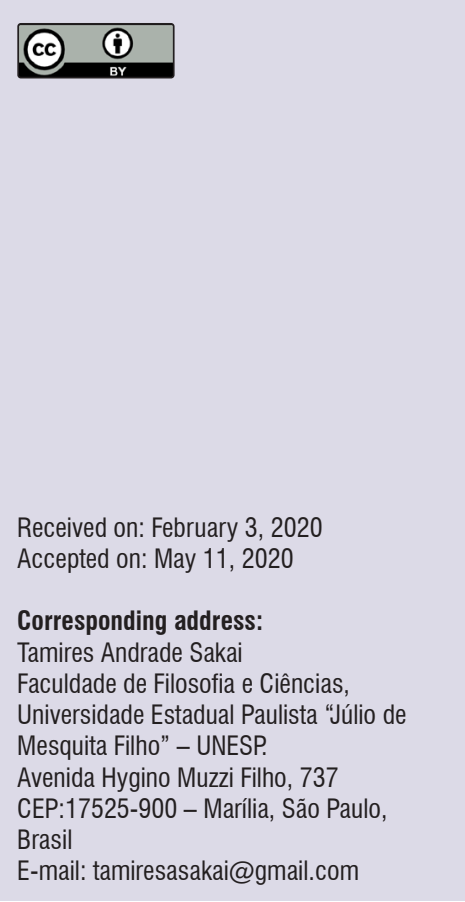

Tamires Andrade Sakai ${ }^{1}$ https://orcid.org/0000-0002-4997-4979

Laura Mochiatti Guijo ${ }^{1}$ https://orcid.org/0000-0003-2351-1105

Dayane Aparecida Nascimento Barbosa ${ }^{2}$ https://orcid.org/0000-0002-8649-128X

Camila Ribas Delecrode ${ }^{2}$ https://orcid.org/0000-0002-9350-216X

Ana Cláudia Vieira Cardoso ${ }^{1}$ https://orcid.org/0000-0001-6808-419X

\section{ABSTRACT}

Purpose: 1) to verify the intervention effects of an informal auditory training program to stimulate auditory abilities for sound localization and sequential memory for verbal and non-verbal sounds, at school environment in a group of preschoolers; 2) to investigate the influence of the gender and age variables on the result of the Simplified Auditory Processing Test (test and retest).

Methods: a prospective, analytical and intervention study developed at a Municipal School of Early Childhood Education. Fifty-one preschool children of both genders, aged between 4 and 6 years, participated in this study. To evaluate the intervention effects of the informal auditory training program, pre-and post-intervention procedures were performed, that is: meatoscopy, tympanometry and Simplified Auditory Processing Test. Appropriate statistical tests were applied, by adopting the $5 \%(0.05)$ significance level.

Results: the comparison of the preschoolers' performance on the test and retest showed a significant improvement in all auditory abilities assessed. Preschoolers showed a better performance in sound localization ability and a worse performance for sequential memory of nonverbal sounds ability, for both test and retest.

Conclusion: in this population, the informal auditory training program showed to be effective and the age variable influenced the result of the Simplified Auditory Processing Test.

Keywords: Auditory Perception; Auditory Perceptual Disorders; Preschool; Acoustic Stimulation 


\section{INTRODUCTION}

Processes needed for language and learning development are quite complex, as they involve networks of neurons distributed in different brain regions, in which their connections are related to speech perception'.

Auditory system is responsible for auditory behavioral phenomena in front of different acoustic signals such as sound localization and lateralization, auditory discrimination, auditory recognition, perception of auditory temporal aspects, perception of acoustic signal in front of other competitive auditory stimulus and auditory performance with degraded acoustic signal, also called auditory closure ability, in which all these behaviors refer to the Central Auditory Processing (CAP) ${ }^{2}$.

The development of auditory abilities and underlying cortical substrates involved in the perception of small changes in sounds occur in a very early age ${ }^{3}$. Disorders in auditory information processing cause difficulties in the interpretation of sound patterns and consequently, can cause impairments for understanding information and school failure ${ }^{4}$.

A study conducted with children aged 8 to 12 years, distributed in a group with disorders related to reading and writing and a control group of children with typical development aimed to compare the performance in the Simplified Auditory Processing Test (SAPT) and Pediatric Speech Intelligibility Test (PSI) and showed that children with learning difficulties had a greater number of alterations in central auditory processing tests ${ }^{5}$.

Another study conducted in a school in the interior of São Paulo whose objective was to evaluate the auditory abilities performance of children with typical development, in an age group from 4 to 6 years, observed that $24.6 \%$ of them had alterations in at least one of the auditory abilities investigated, with a higher occurrence of alterations for younger children. In view of this result, the authors stated that the programs for investigation and monitoring of middle ear conditions and auditory abilities in pre-school and school age can eliminate or minimize complications that would alter sociolinguistic development ${ }^{6}$.

In accordance with the compiled literature and in order to compensate a possible delay in the development of auditory abilities, it is recommended to carry out a study to stimulate these abilities through an auditory training program. One of the fundamentals of auditory training is the promotion of the central nervous system plasticity ${ }^{7}$, which is defined as the way that the nervous system changes continuously through an intense auditory stimulation ${ }^{8}$.

Some authors ${ }^{9}$ report that electrophysiological data recorded after the application of auditory training programs demonstrate beneficial neurophysiological changes in the central auditory nervous system, probably in response to sensory experiences or by an increase in the number of neurons that respond positively to sensory information ${ }^{10}$.

Auditory training refers to the set of acoustic conditions and tasks that are applied to activate hearing in such a way that its neural basis and auditory behaviors are modified, promoting benefits for auditory performance ${ }^{7}$. A study verified that auditory training was able to stimulate neural structures related to the performance of trained auditory abilities ${ }^{10}$. The auditory abilities developed by the efficient interpretation of the acoustic signal have improved and become more refined with growth ${ }^{11}$, which is essential for the occurence of effective communication.

Based on the above, the objectives of this study were 1) to verify the intervention effects of an informal auditory training program to stimulate auditory abilities for sound localization and sequential memory for verbal and non-verbal sounds, at school environment in a group of pre-schoolers; 2) to investigate the influence of gender and age variables on the result of the Simplified Auditory Processing Test (test and retest). The findings of this study can foster discussions regarding the performance of informal auditory training and its consequences in the modification of neural structures responsible for sounds processing, as well as demonstrate that informal auditory training can be effective to improve the stimulated auditory abilities of preschoolers.

\section{METHODS}

The research design was prospective, analytical and interventional. This project was approved by the Research Ethics Committee of the Faculty of Philosophy and Sciences of the São Paulo State University "Júlio de Mesquita Filho" (UNESP) - Marília, Brazil, under no 132/2010 and all those responsible for the study participants signed the Informed Consent Form (ICF).

This research was developed in a Municipal School of Early Childhood Education located in a peripheral region of the municipality of Marília, São Paulo, Brazil, attended by a population of low socioeconomic level.

In this study, participants were chosen following the inclusion criteria: attending school full time and; being 
in the age group from 4 to 6 years; having participated in all meetings of the auditory abilities stimulation program conducted at school. The exclusion criteria were: absence of signature of the informed consent form by the parents and failure to perform the test or retest in the Simplified Auditory Processing Test (SAPT).

Thus, 51 preschoolers, 25 females and 26 males, participated in this study. Regarding the age group, 25 were aged 4 years to 4 years and 11 months and 26 aged 5 years to 6 years and 2 months.

Initially, the selection of participants that fit the inclusion criteria was carried out. Meatoscopy was conducted to verify possible alterations which prevent the performance of other procedures. Regarding tympanometry, results were analyzed based on the classification proposed by Jerger $(1970)^{12}$. Normal tympanometry was considered when the preschooler had bilateral type A tympanometric curve, indicating normal mobility of the tympanic-ossicular system.

The procedure used to assess the intervention effects of the auditory abilities stimulation program (test and retest) was SAPT. SAPT comprised the following tests: sound localization (SL) in five directions and sequential memory for verbal sounds (SMV) and non-verbal sounds (SMNV), as proposed by the literature ${ }^{13}$. For this assessment, preschoolers were instructed through demonstration and instructed to keep their eyes closed.

The SL test was applied using a "bell" instrument to assess the localization ability in five directions: on the right, on the left, in front, behind and above. The response requested from the participants was to indicate the direction in which the stimulus was presented. It was considered as a normality criterion to answer correctly four or five directions, as long as the right and left were located correctly ${ }^{13}$.

The SMV and SMNV tests assessed the auditory ability of memory for sounds in sequence or temporal ordering $^{10}$. To investigate the SMV, the syllables "PA", "TA" and "CA" were used in three different sequences, being initially requested the isolated repetition of each syllable. The requested answer was to repeat the presented sequence and the normal repetition of at least two sequences of the three presented was considered as a normality criterion ${ }^{13}$. To assess SMNV, three instruments were used: bell, rattle and coconut. The stimuli were presented in three different sequences and the requested response was pointing out the instruments in the order in which they were presented. The normality criterion was to correctly point at least two sequences out of the three presented ${ }^{13}$.

The auditory abilities stimulation program was structured to run for 30 minutes, twice a week for a period of one month. The activities focused on orientation tasks and stimulation of the SL, SMV and SMNV auditory abilities.

The activities were developed in the classroom and conducted with four different classes, two classes of children aged 4 years to 4 years and 11 months (Child class $(\mathrm{A}$ and $\mathrm{B}$ ) and two classes of children aged 5 years to 6 years and 2 months (Child class II A and B). Materials used and activities developed during the stimulation program are described in a chart format (Figure 1). 


\begin{tabular}{|c|c|c|c|}
\hline Day & Objective & Resource & Activity \\
\hline $1^{\text {st }}($ September 11) & $\begin{array}{c}\text { - To explain the anatomophysiology } \\
\text { of the auditory system and hearing } \\
\text { care. }\end{array}$ & $\begin{array}{l}\text { - Human ear model; } \\
\text { - Drawing printed of the ear; } \\
\text { - Colored pencils. }\end{array}$ & $\begin{array}{c}\text { - Explanatory lecture; } \\
\text { - Painting of an ear drawing. }\end{array}$ \\
\hline $2^{\text {nd }}$ (September 14) & $\begin{array}{l}\text { - To stimulate auditory ability of } \\
\text { sound localization; } \\
\text { - To stimulate auditory recognition } \\
\text { for verbal and non- verbal sounds; } \\
\text { - To restart the explanations about } \\
\text { the anatomophysiology of the } \\
\text { auditory system. }\end{array}$ & $\begin{array}{c}\text { - Musical instruments; } \\
\text { - CD with different verbal and non- } \\
\text { verbal sounds; } \\
\text { - CD "Singing and Learning" } 14 \\
\text { (track 1): music about hearing. }\end{array}$ & $\begin{array}{l}\text { - Activity to point out the direction } \\
\text { in which the stimulus was } \\
\text { presented with closed eyes sitting } \\
\text { in a cricle; } \\
\text { - Recognition and naming of CD } \\
\text { sounds; } \\
\text { - Listen to and sing educational } \\
\text { music. } \\
\end{array}$ \\
\hline $3^{\text {rd }}$ (September 18) & $\begin{array}{l}\text { - To stimulate attention and } \\
\text { auditory closure ability; } \\
\text { - To stimulate auditory ability for } \\
\text { sequential memory for verbal } \\
\text { sounds. }\end{array}$ & $\begin{array}{c}\text { - CD "Processing sounds"15 } \\
\text { (Track 16) }\end{array}$ & $\begin{array}{l}\text { - Exercise to complete verses and } \\
\text { songs when requested using CD; } \\
\text { "Cordless phone" play }\end{array}$ \\
\hline $4^{\text {th }}($ September 25) & $\begin{array}{l}\text { - To stimulate auditory attention } \\
\text { and sequential memory for non- } \\
\text { verbal sounds abilities; } \\
\text { - To recognize verbal and non- } \\
\text { verbal sounds. }\end{array}$ & $\begin{array}{l}\text { - CD "Processing sounds" } 15 \\
\text { (Tracks } 18 \text { to 21); } \\
\text { CD "Processing sounds" } 15 \\
\text { (Tracks } 22 \text { and 23) }\end{array}$ & $\begin{array}{l}\text { - Activity to pay attention and count } \\
\text { how many times the onomatopoeic } \\
\text { sounds appeared in the song; } \\
\text { - Recognition and naming of the } \\
\text { sounds presented. }\end{array}$ \\
\hline $5^{\text {th }}$ (October 2) & $\begin{array}{l}\text { - To stimulate attention and } \\
\text { auditory memory abilities; } \\
\text { - To stimulate auditory attention } \\
\text { ability, memory and inter- } \\
\text { hemispheric integration. }\end{array}$ & $\begin{array}{l}\text { - CD with children's story narrative; } \\
\text { - CD with the song "I shot the stick } \\
\text { in the cat". }\end{array}$ & $\begin{array}{l}\text { - Listen to the narrative and retell it; } \\
\text { - Listen, sing the song and clap to } \\
\text { its rhythm. }\end{array}$ \\
\hline $6^{\text {th }}$ (October 5) & $\begin{array}{l}\text { - To stimulate sequential memory } \\
\text { for verbal sounds and auditory } \\
\text { figure- ground ability and inter- } \\
\text { hemispheric integration; } \\
\text { - To stimulate auditory abilities of } \\
\text { attention and sequential memory } \\
\text { for verbal sounds and inter- } \\
\text { hemispheric integration. }\end{array}$ & $\begin{array}{l}\text { - Ball and CD with varied music; } \\
\text { - CD with Xuxa's song "Head, } \\
\text { shoulder, knee and foot". }\end{array}$ & $\begin{array}{l}\text { - Activity of playing a ball } \\
\text { associated with repetition of words } \\
\text { in the presence of a song; } \\
\text { - Sing the song and perform the } \\
\text { requested movements. }\end{array}$ \\
\hline $7^{\text {th }}$ (October 9) & $\begin{array}{l}\text { - To stimulate auditory recognition } \\
\text { for non- verbal sounds, auditory } \\
\text { memory and temporal ordering } \\
\text { abiities; } \\
\text { To stimulate attention and auditory } \\
\text { memory for verbal and non- verbal } \\
\text { sounds ability. }\end{array}$ & $\begin{array}{c}\text { - CD "Auditory abilities and } \\
\text { phonological awareness from } \\
\text { theory to practice" } 16 \text { (Tracks } 1 \\
\text { to 3) and cards containing the } \\
\text { corresponding images; } \\
\text { - CD "Processing sounds vol.2" } 15 \\
\text { (Track 1) }\end{array}$ & $\begin{array}{l}\text { - Listen to the sound stimuli and } \\
\text { point the respective images in the } \\
\text { order presented; } \\
\text { - Listen to the narrative and retell it. }\end{array}$ \\
\hline $8^{\text {th }}($ October 10$)$ & $\begin{array}{l}\text { - To resume the concepts and } \\
\text { investigate the learned content; }\end{array}$ & $\begin{array}{c}\text { - CD "Singing and Learning" } 14 \\
\text { with educational music about the } \\
\text { auditory system; } \\
\text { - Paper sheet and pencil. }\end{array}$ & $\begin{array}{l}\text { - Resumption of concepts about } \\
\text { the importance of hearing and care } \\
\text { with it; } \\
\text { - Listening and singing educational } \\
\text { music about the ear; } \\
\text { - Request drawing about the ear. }\end{array}$ \\
\hline
\end{tabular}

Caption: $\mathrm{Vol}=$ Volume

Figure 1. Auditory abilities stimulation program in preschoolers 


\section{RESULTS}

Initially the results were analyzed test by test and classified as normal or abnormal. Preschoolers "PASSED" in SAPT when they had answers compatible with the normality pattern in the three tests applied.

In order to verify the degree of relationship between the variables "result of tympanometry" and "SAPT (test and retest)", Spearman's Correlation was applied. (Table 1). As the statistical analysis showed that tympanometry had a 'weak' and non-significant correlation with the results of the auditory processing assessment, it was decided to group the independent data of tympanometry. Regarding the results of tympanometry in the test stage, $26(51 \%)$ children had bilateral type A tympanometric curve and, in the retest stage, $30(59 \%)$ had this type of curve. It should also be noted that in the test stage, $16(31.4 \%)$ had a type A curve unilaterally and, $11(21.6 \%)$ in the retest stage.

Table 1. Correlation of tympanometry results and Simplified Auditory Processing Test (test and retest) in preschoolers

\begin{tabular}{cccc}
\hline \multirow{2}{*}{ SAPT } & Statistics & \multicolumn{2}{c}{ TIMPANOMETRY } \\
\cline { 3 - 4 } & Coef. Correl. $(r)$ & -0.096 & Retest \\
\hline \multirow{2}{*}{ SMNV } & Sig. $(p)$ & 0.504 & -0.087 \\
& $N$ & 51 & 0.544 \\
& Coef. Correl. $(r)$ & -0.157 & 51 \\
\hline \multirow{2}{*}{ SMV } & Sig. (p) & 0.270 & -0.146 \\
& $N$ & 51 & 0.308 \\
& Coef. Correl. $(r)$ & -0.263 & 51 \\
\hline \multirow{2}{*}{$S L$} & Sig. $(p)$ & 0.062 & -0.060 \\
& $N$ & 51 & 0.678 \\
& $N$ & & 51 \\
\hline
\end{tabular}

Statistically non-significant values $(\mathrm{p} \leq 0.05)$ - Spearman's Correlation Analysis

Caption: SAPT = Simplified Auditory Processing Test; SMNV = sequential memory for non-verbal sounds; SMV $=$ sequential memory for verbal sounds; SL $=$ sound localization

The comparison between the preschoolers' performance in the test and retest stages was conducted using the Cramér's $V$ Statistics Test, and the significance level of $5 \%(0.05)$ was adopted. This comparison showed that there was a significant improvement in all the auditory abilities assessed. The auditory ability for $S L$ was the one that preschoolers had the best performance and the SMNV had the worst performance, both in the test and retest stages (Table 2). 
Table 2. Preschoolers' performance in the Simplified Auditory Processing Test in the test and retest

\begin{tabular}{|c|c|c|c|c|c|}
\hline \multirow{2}{*}{\multicolumn{2}{|c|}{ TEST }} & \multicolumn{2}{|c|}{ RETEST } & \multirow{2}{*}{ Total } & \multirow{2}{*}{$P$ value } \\
\hline & & Normal & Altered & & \\
\hline \multirow{6}{*}{ SMV } & \multirow{2}{*}{ Normal } & 33 & 0 & 33 & \multirow{6}{*}{$0.016^{*}$} \\
\hline & & $64.70 \%$ & $0.00 \%$ & $64.70 \%$ & \\
\hline & \multirow{2}{*}{ Altered } & 15 & 3 & 18 & \\
\hline & & $29.40 \%$ & $5.90 \%$ & $35.30 \%$ & \\
\hline & \multirow{2}{*}{ Total } & 48 & 3 & 51 & \\
\hline & & $94.10 \%$ & $5.90 \%$ & $100.00 \%$ & \\
\hline \multirow{6}{*}{ SMNV } & \multirow{2}{*}{ Normal } & 17 & 0 & 17 & \multirow{6}{*}{$0.002^{*}$} \\
\hline & & $33.30 \%$ & $0.00 \%$ & $33.30 \%$ & \\
\hline & & 20 & 14 & 34 & \\
\hline & Altered & $39.20 \%$ & $27.50 \%$ & $66.70 \%$ & \\
\hline & \multirow{2}{*}{ Total } & 37 & 14 & 51 & \\
\hline & & $72.50 \%$ & $27.50 \%$ & $100.00 \%$ & \\
\hline \multirow{6}{*}{ SL } & \multirow{2}{*}{ Normal } & 44 & 0 & 44 & \multirow{6}{*}{$0.011^{*}$} \\
\hline & & $86.30 \%$ & $0.00 \%$ & $86.30 \%$ & \\
\hline & Altorod & 6 & 1 & 7 & \\
\hline & Alterea & $11.80 \%$ & $2.00 \%$ & $13.70 \%$ & \\
\hline & \multirow{2}{*}{ Total } & 50 & 1 & 51 & \\
\hline & & $98.00 \%$ & $2.00 \%$ & $100.00 \%$ & \\
\hline
\end{tabular}

*Statistically significant values $(\mathrm{p} \leq 0.05)$ - Cramér's V test.

Caption: SMNV = sequential memory for non-verbal sounds; SMV = sequential memory for verbal sounds; SL = sound localization

Regarding the pass-failure criterion for the Simplified Auditory Processing Test, it was observed that only $25.5 \%(n=13)$ of preschoolers passed in the test, and after the stimulation program the occurrence increased to $70.6 \%(\mathrm{~N}=36)$ and this correlation was significant (Table 3).

Table 3. Comparison of the preschoolers' performance in the Simplified Auditory Processing Test, test and retest

\begin{tabular}{|c|c|c|c|c|c|c|}
\hline \multirow{3}{*}{ SAPT } & \multicolumn{4}{|c|}{ Category } & \multirow{3}{*}{$\begin{array}{l}\text { Total of tested/ } \\
\text { retested } \\
\text { participants }\end{array}$} & \multirow{3}{*}{$P$ value } \\
\hline & \multicolumn{2}{|c|}{ TEST } & \multicolumn{2}{|c|}{ RETEST } & & \\
\hline & Passed (N) & Failed (N) & Passed (N) & Failed (N) & & \\
\hline & $\begin{array}{c}13 \\
25.50 \%\end{array}$ & $\begin{array}{c}38 \\
74.50 \%\end{array}$ & $\begin{array}{c}36 \\
70.60 \%\end{array}$ & $\begin{array}{c}15 \\
29.40 \%\end{array}$ & $\begin{array}{c}51 \\
100 \%\end{array}$ & $0.007^{*}$ \\
\hline
\end{tabular}

*Statistically significant values ( $\mathrm{p} \leq 0.05)$ - Cramér's V test.

The Likelihood-Ratio Test was applied to investigate the influence of the gender and age variables on result of the Simplified Auditory Processing Test (test and retest). This analysis demonstrated that the preschoolers' performance on SAPT was not influenced by the gender variable (Table 4 ).
However, it was found that the preschoolers' performance in SAPT was influenced by the variable "age" and that this relationship was significant (Table 5). 
Table 4. Preschoolers' performance in the Simplified Auditory Processing Test, according to the gender variable

\begin{tabular}{|c|c|c|c|c|c|c|}
\hline \multirow{3}{*}{ SAPT } & \multirow{3}{*}{ Category } & \multicolumn{4}{|c|}{ Gender } & \multirow{3}{*}{$P$ value } \\
\hline & & \multicolumn{2}{|c|}{ Females } & \multicolumn{2}{|c|}{ Males } & \\
\hline & & $\mathbf{N}$ & $\%$ & $\mathbf{N}$ & $\%$ & \\
\hline \multirow{2}{*}{ Test } & Passed & 7 & 28.00 & 6 & 23.10 & \multirow{2}{*}{$0.687^{* *}$} \\
\hline & Failed & 18 & 72.00 & 20 & 76.90 & \\
\hline \multirow{2}{*}{ Retest } & Passed & 16 & 64.00 & 20 & 76.90 & \multirow{2}{*}{$0.311^{* *}$} \\
\hline & Failed & 9 & 36.00 & 6 & 23.10 & \\
\hline
\end{tabular}

** Statistically significant values $(\mathrm{p} \leq 0.05)$ - Likelihood-ratio test

Caption: SAPT $=$ Simplified Auditory Processing Test

Table 5. Preschoolers' performance in the Simplified Auditory Processing Test, according to the age group variable

\begin{tabular}{|c|c|c|c|c|c|c|}
\hline \multirow{3}{*}{ SAPT } & \multirow{3}{*}{ Category } & \multicolumn{4}{|c|}{ Age group } & \multirow{3}{*}{$P$ value } \\
\hline & & \multicolumn{2}{|c|}{$4 y-4 y 11 m$} & \multicolumn{2}{|c|}{$5 y-6 y 2 m$} & \\
\hline & & $\mathrm{N}$ & $\%$ & N & $\%$ & \\
\hline \multirow{2}{*}{ Test } & Passed & 3 & 12.00 & 10 & 38.50 & \multirow{2}{*}{$0.030^{*}$} \\
\hline & Failed & 22 & 88.00 & 16 & 61.50 & \\
\hline \multirow{2}{*}{ Retest } & Passed & 14 & 56.00 & 22 & 84.60 & \multirow{2}{*}{$0.025^{\star}$} \\
\hline & Failed & 11 & 44.00 & 4 & 15.40 & \\
\hline
\end{tabular}

* Statistically significant values $(p \leq 0.05)$ - Likelihood-ratio test

Caption: SAPT $=$ Simplified Auditory Processing Test

\section{DISCUSSION}

This study found a significant improvement in the preschoolers' performance in the Simplified Auditory Processing Test, after completing the auditory abilities stimulation program. This result confirmed that the studied population lacks adequate stimuli that promote the auditory pathway maturation process.

These findings allow us to affirm that the informal auditory training program applied to this population was effective, since the majority of preschoolers showed improvement in performance in all the auditory abilities assessed, and that this relationship was significant.

It should also be emphasized that the sound localization was the auditory abilitiy with the highest index of correct answers, and that the sequential memory for non-verbal sounds with the worst index, in both stages (test and retest).

A previous study showed that schoolers had greater difficulty in memorizing sound sequences than locating the sound source ${ }^{11}$, a finding that corroborates the results of this study. Such result can be explained by the chronology of the auditory abilites acquisition, in which the sound localization is one of the abilities that develops earlier, and it is emphasized that from 3 years and a half the child is able to locate the sound source in five directions (right, left, back, up and ahead) ${ }^{17}$.
In this study, even after the training program, 27.5\% of preschoolers still show alterations in the sequential memory test for non-verbal in sequence. This test assessed a simple temporal ordering ability, which is a prerequisite for language skills, and it is through it that the individual is able to discriminate correctly the execution order of sounds over time. Children with alteration in this ability may have difficulties in distinguishing sound relationships of suprasegmental traits of the speech, prosody, frequency, intensity, timbre, difficulty in perceiving differences between the acoustic characteristics of sounds ${ }^{18}$, also reading and writing difficulties ${ }^{19}$.

The investigation of the influence of gender and age variables on the result of the Simplified Auditory Processing Test (test and retest) demonstrated that the gender variable did not interfere with the preschoolers' performance. However, the age variable influenced the preschoolers' results in SAPT. The age group with the highest occurrence of alterations was 4 years. The increase in chronological age shows a permanent neuronal development, which is improved by the sensory experiences acquired ${ }^{19}$, thus the older the better the performance in tests.

A previous study ${ }^{11}$ demonstrated the influence of the age and sex variables on the students' performance 
for the sound localization test. The analysis of results showed that students who were in the age group from 9 to 10 years had better performance when compared to the younger ones, aged 5 to 8 years; and that female schoolers performed better, and this difference was significant.

Still regarding influence of the variable "age", another study investigated the simple temporal ordering and sound localization abilities of children aged 4 to 5 years. The analysis of findings showed that the 5-year-old children performed better in SAPT ${ }^{20}$, data which corroborates the findings of this study.

In literature there was a scarcity of studies that investigated the auditory abilities stimulation in a school environment, in most publications the objective was to assess central auditory processing abilities ${ }^{11,21-25}$ or to train auditory abilities in a clinical environment ${ }^{8,26}$.

Researchers carried out a stimulation program of the auditory-verbal abilities to schoolers at elementary school in a school environment. This study was developed with 22 pre-syllabic schoolers, aged 6 years and 1 month to 6 years and 9 months. This stimulation program was conducted in 15 sessions, lasting from 15 to 30 minutes. They concluded that the stimulation program was appropriate to the reality of the school and to the stimulated children, as there was a positive correlation between attendance and the growth rate at the phonemic level ${ }^{27}$.

It is relevant to emphasize that the preschoolers who participated in this study are in different periods of acquisition and development of the phonological system and that the results regarding their performance for the tested abilities may have been influenced by the previously acquired sounds. Studies conducted in the area of speech sound disorders have investigated the relationship between temporal auditory processing and the constituent aspects of sounds, such as patterns of pitch, duration, time intervals and temporal organization, mainly in altered speech, due to the ability to perceive subtle acoustic changes is extremely relevant for the phoneme perception, either by the presence of a disorder or by the phonological acquisition process ${ }^{28}$.

Based on the findings of this study and gaps in the literature, there is a need for further research on the benefits of implementing informal auditory training programs in the school environment. These programs need to be developed with several populations that are at risk of central auditory processing and language disorder, whether in spoken and/or written form.

\section{CONCLUSION}

In the population studied, the informal auditory training program was effective and the age variable influenced the result of the Simplified Auditory Processing Test.

\section{REFERENCES}

1. Machado CSS, Valle HLBS, Paula KM, Lima SS. Caracterização do processamento auditivo das crianças com distúrbio de leitura e escrita de 8 a 12 anos em tratamento no Centro Clínico de Fonoaudiologia da Pontifícia Universidade Católica de Minas Gerais. Rev. CEFAC. 2011;13(3):504-12.

2. ASHA: American Speech and Hearing Association [Internet]. Rockville: American-LanguageHearing Association; c 2005. (Central) Auditory processing disorders. [Internet]. [cited 2007 Mar 10]; Disponível em: http://www.asha.org/members/ deskrefjournals/deskref/default.

3. Jensen JK, Neff DL. Development of basic auditory discrimination in preschool children. Psychol Sci. 1993;4(2):104-7.

4. Carvalho NG, Novelli CVL, Colella-Santos MF. Factors in childhood and adolescence that may influence the auditory processing: a systematic review. Rev. CEFAC. 2015;17(5):1590-603.

5. Pelitero MT, Manfredi AKS, Schneck APC. Avaliação das habilidades auditivas em crianças com alterações de aprendizagem. Rev. CEFAC. 2010;12(4):662-70.

6. Buriti AKL, Rosa MRD. Percepção auditiva em escolares com dislexia: uma revisão sistemática. Rev. Psicopedag. 2014;31(94):82-8.

7. Musiek FE, Chermak GD, Weihing J. Auditory training. In: Chermak GD, Musiek FE (eds). Handbook of Central Auditory Processing Disorder: Comprehensive Intervention. San Diego: Plural Publishing; 2013. p. 77-106.

8. Castan ATM, Luiz CBL, Gil D. Acoustically controlled auditory training in an adult after traumatic brain injury. Rev. CEFAC. 2017;19(1):126-34.

9. Kappel V, Moreno ACP, Buss CH. Plasticidade do sistema auditivo: considerações teóricas. Braz. J. Otorhinolaryngol. 2011;77(5):670-4.

10. Ávila RRA, Murphy CFB, Schochat E. Efeitos do treinamento auditivo em idosos com comprometimento cognitivo leve. Psicol. Reflex. Crit. 2014;27(3):547-55. 
11. Collela-Santos MF, Bragato GR, Martins PMF, Dias $A B$. Triagem auditiva em escolares de 5 a 10 anos. Rev. CEFAC. 2009;11(4):1-10.

12. Jerger J. Clinical experience with impedance audiometry. Arch Otolaryngol, Oct. 1970;92(4):311-24.

13. Pereira LD, Schochat E. Testes comportamentais para avaliação do processamento auditivo. Barueri: Pró-fono; 2011. p.39-42.

14. Munhoz LC. Cantando e aprendendo a mastigar, a ouvir, a respirar e a falar. - Guia para promoção da saúde em instituições educacionais: uma visão fonoaudiológica - 1.ed. São Paulo: Lovise; 2002.

15. Rodrigues FMC. Processando Sons I (Livro e software). 1.ed. Ribeirão Preto: Booktoy; 2007.

16. Knobel KAB, Nascimento LCR. Habilidades auditivas e consciência fonológica: da teoria à prática (CD de Estímulos Auditivos). 1.ed. Barueri: Pró-Fono; 2009.

17. Pereira LD, Cavadas M. Processamento auditivo central. In: Frota $S$ (org). Fundamentos em Fonoaudiologia: Audiologia. Rio de Janeiro: Guanabara Koogan; 1998. p.135-46.

18. Arnaut MA, Agostinho CV, Pereira LD, Weckx LLM, Ávila CRB. Processamento auditivo em crianças disfônicas. Braz. j. otorhinolaryngol. 2011;77(3):362-8.

19. Mourão AM, Esteves CC, Labanca L, Lemos SM. Desempenho de crianças e adolescentes em tarefas envolvendo habilidade auditiva de ordenação temporal simples. Rev. CEFAC. 2012; 4(4): 659-68.

20. Souza MA, Passaglio NJS, Souza VC, Scopel RR, Lemos SMA. Temporal ordering and sound localization: association with environment and language development. Audiol., Commun. Res. 2015;20(1):24-31.

21. Musiek FE, Rintelmann WF. Perspectivas atuais em avaliação auditiva. 1.ed. São Paulo: Manole; 2001.

22. Campos $\mathrm{CAH}$. Tratado de otorrinolaringologia. 1.ed. São Paulo: Roca; 2004.

23. Zanchetta S, Tazinazzio TG, Colon JC, Rodrigues PMT. A triagem no processamento auditivo central como instrumento na identificação de alterações auditivas em pré-escolares. Temas Desenvolv. 2000;9(50):28-32.

24. Engelmann L, Ferreira MIDC. Avaliação do processamento auditivo em crianças com dificuldades de aprendizagem. Rev. Soc. Bras. Fonoaudiol. 2009;14(1):69-74.
25. Abdo AGR, Murphy CFB, Schochat E. Habilidades auditivas em crianças com dislexia e transtorno do déficit de atenção e hiperatividade. Pró-Fono $R$. Atual. Cient. 2010;22(1):25-30.

26. Samelli AG, Mecca FFDN. Treinamento auditivo para transtorno do processamento auditivo: uma proposta de intervenção terapêutica. Rev. CEFAC. 2009;12(2):1-7.

27. Toffoli MB, Lamprecht RR. A estimulação de habilidades auditivo-verbais de crianças pré-silábicas: contribuições para o desenvolvimento da consciência fonológica. Let Hoje. 2008;43(3):89-97.

28. Balen SA, Boeno MRM, Liebel G. A influência do nível socioeconômico na resolução temporal em escolares. Rev. Soc. Bras. Fonoaudiol. 2010;15(1):7-13. 